БІООРГ АНІЧНА ХІМІЯ

\title{
Newly synthesized carbocyanine fluorescent probes, their characteristics and behavior in proliferating cultures
}

\author{
E. I. Goncharuk, I. A. Borovoy' ${ }^{1}$ E. V. Pavlovich, Yu. V. Malyukin'1, V. I. Grischenko
}

Institute for Problems of Cryobiology and Cryomedicine of the NAS of Ukraine

23, Pereyaslavskaya Str., Kharkiv, Ukraine, 61015

${ }^{1}$ State Scientific Institution «Institute for Single Crystals» NAS of Ukraine

60, Lenin Ave., Kharkiv, Ukraine, 61001

lenapavlovich@gmail.com

\begin{abstract}
Aim. To study possibile application of C2, C9, C18 and JC-1 carbocyanine fluorescent dyes for cell culture characterization. Methods. Morphological methods, fluorescence-activated cell sorting (FACS) analysis, luminescent microscopy were used. Results. The studied carbocyanine probes were shown to be preserved in dividing cells for at least 4 duplications. It was found that carbocyanine probe JC-1 did not transit from cell to cell under combined culturing of labeled and non-labeled cells. Conclusions. The paper covers the use of carbocyanine fluorescent probes for long-term culturing of cell lines. Probes C 9 and JC-1 were optimal for the proliferative culture observation, allowing to trace mitochondrial functional state.
\end{abstract}

Key words: fluorescence, probes, human fibroblasts, cell culture.

Introduction. Investigations of the cell cultures functioning require informative express methods. One of them is the labeling of different cell components with luminescent probes. It is evident that an agent introduced into a cell should be non-toxic and affect minimally the vital cell processes. Long-term stay of a fluorescent label inside a cell is also desirable. The dyes with the abovementioned properties may be used for diagnostics of the cell culture state under various physical and chemical influences. A next prospect is the coding of biological samples, e. g. during their storage in cryobanks or when transporting them.

In addition, the cytological and histological studies for tracing the fate of transplanted cell in a recipient's organism require the use of long-living probes, provi-

(C) Institute of Molecular Biology and Genetics NAS of Ukraine, 2009 ding the information on the processes occurring in cells and tissues during their vital activity.

We have synthesized and investigated the carbocyanine dyes differing in their hydrophilic-hydrophobic features. As it has been reported [1] the staining with these dyes was performed prior to investigating and there are only single papers on culturing cell lines with integrated dyes $[2,3]$. The research was aimed at comparative characterization of the behavior of syn- thesized by us probes in proliferating cell cultures.

The study comprised the examining of localization of probes in a cell, duration of their storage and investigation of the possibility of free intercellular transition of the probes during combined culturing of two cell lines.

Materials and Methods. Fluorescent probes C2 (3,3'-diethyloxacarbocyanine bromide), C9 (3,3'-dide- 
cyloxacarbocyanine bromide), C18 (3,3'-dioctadecyloxacarbocyanine bromide) and JC-1 (5,5',6,6'-tetrachlor-1,1',3,3'-tetraethyl-benzoimidazolylcarbocyanine iodide) were synthesized at the Institute of Scintillation Materials of the State Scientific Institution «Institute for Single Crystals» NAS of Ukraine. When staining the cell we used solutions of probes with concentration from $0.1 \mu \mathrm{M}$ to $100 \mu \mathrm{M}$.

The behavior of probes has been studied in the cells of human fibroblast (HF) diploid line and in the cells of porcine embryo kidney (SPEV). The cells were cultured in Dulbecco's modified Eagle's Medium (DMEM) (Sigma) with adding $10 \%$ fetal calf serum (FCS) (HyClone) [4]. The number of viable cells was counted on staining with trypan blue supravital dye. The probes were integrated into the cell monolayer and cell suspension, obtained enzymatically with following washing-out with Hank's solution. The cells in suspended state were incubated with probes for $15 \mathrm{~min}$, afterwards a non-bound dye was washed-out by adding Hank's solution into suspension in 9:1 ratio and centrifuged at $1,000 \mathrm{rot} / \mathrm{min}$.

Afterwards the stained with fluorescent dyes cells were cultured at $37{ }^{\circ} \mathrm{C}$ and $5 \% \mathrm{CO}_{2}$ [5]. The distribution of dye in cells was assessed using inverted fluorescent microscope Olympus IX71 with digital camera Olympus C-5060, the excitation band was 450 $490 \mathrm{~nm}$. Probe toxicity was tested by morphology and proliferative activity of probe-labeled cells within in vitro experiments.

The flow cytometry investigations were performed with FACS Calibur cytofluorimeter (Becton-Dickinson, USA) using reagents of the same company. Prior to the analysis the cells were suspended, washed-out from nutritive medium and placed into isotonic solution. The cells were incubated with working concentrations of the probes within $15 \mathrm{~min}$. The results obtained by flow cytometry were analysed with Win MDI v.2.8 software and presented as point graphs.

To find out whether the adherence of fluorescent probes is potential-dependent, the proton translocator carbonylcyanide $p$-trifluoromethoxyphenylhydrazone (FCCP) was used [6]. FCCP at of $5 \mu \mathrm{M}$ concentration was added to a proliferating cell culture after staining with fluorescent probes. The luminescence changes in cells were estimated by luminescent microscopy.
To induce apoptosis, $10 \mu \mathrm{M}$ etoposide was introduced into the medium for $24 \mathrm{~h}$ with subsequent double washing-out.

To examine the possibility of transition of fluorescent probes from stained cells into non-stained ones a method of co-culturing was applied. In the first case the cells of HF culture were stained and the SPEV were not, in the other case - vice-versa. After staining, the cells were plated together with non-stained ones into one flask on a glass and cultured for $2-3$ days at $37{ }^{\circ} \mathrm{C}$ and $5 \% \mathrm{CO}_{2}$. Distribution of dye in the cells was evaluated by luminescent microscopy.

For the assessment of survival duration of the fluorescent probes in the proliferating culture stained with fluorescent dyes, the cells were cultured under standard conditions for 10 days. During this term the presence and intensity of luminescence were examined.

Results. Carbocyanine dyes have been widely used in fluorescent labeling of cells and tissues since the late $70 \mathrm{~s}$. Iodides and perchlorates have been used as counter-ions. The synthesized by us dyes C2, C9 and C18 differed in using $\mathrm{Br}$-anions for this purpose. Herewith the $\mathrm{C} 2$ dye is well soluble in water, and the probe $\mathrm{C} 18$ is poorly soluble, but due to its highly hydrophobic behavior it integrates into membrane lipid areas. This difference in hydrophilic-hydrophobic properties is determined by the length of alkyl substituents at nitrogen atom of oxazole cycle. The dye C9 was synthesized additionally as a probe with intermediate properties due to the presence of alkyl «tails», consisting of 9 carbon atoms in the molecule. The JC-1 dye was obtained by the method [7]. This dye exists in two forms: monomeric, fluorescing at $527 \mathrm{~nm}$ (green fluorescence) and as J-aggregates with emission at $590 \mathrm{~nm}$ (orange fluorescence) with $490 \mathrm{~nm}$ excitation wave length (Fig. 1).

The dyes C2, C9, C18 were synthesized according to the methods [8]. The probes structures are shown on the scheme.

Absorption and luminescence spectra of probes $\mathrm{C} 2$, C9 and C18 measured in chloroform are identical (within the measurement conditions) for all the dyes, with fluorescence maximum at $515 \mathrm{~nm}$ (Fig. 2).

At the first stage of research the influence of carbocyanine probes on the morphology and proliferative activity was examined in vitro. During incubation of the cells within the media with various content of fluo- 


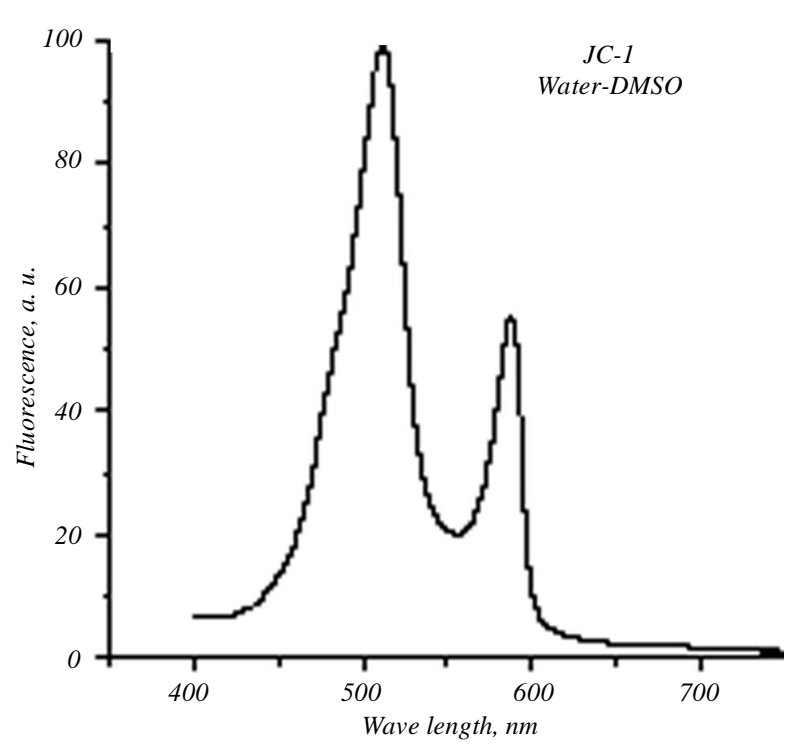

Fig. 1. Fluorescence spectrum of JC-1 dye in dimethyl sulfoxide

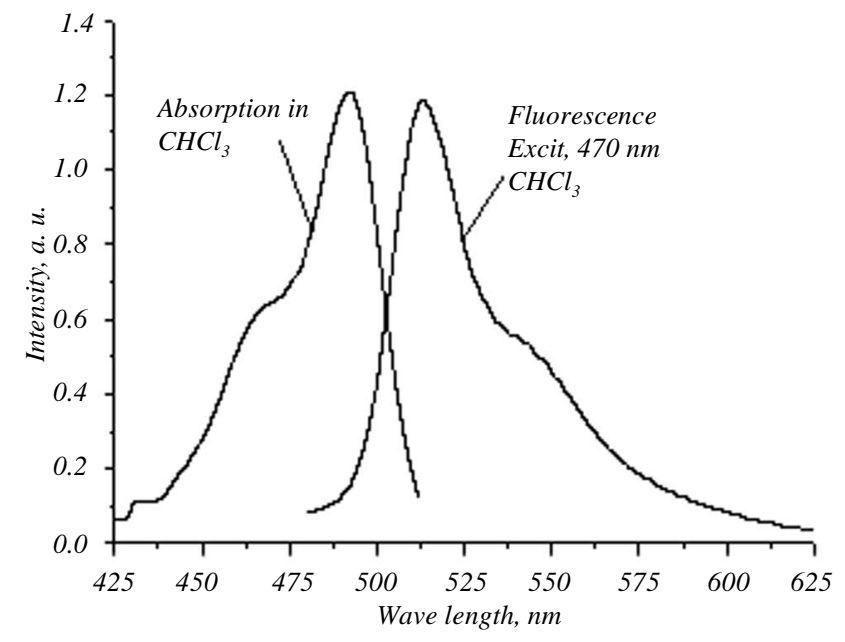

Fig. 2. Absorption and luminescence spectra of $\mathrm{C} 2, \mathrm{C} 9, \mathrm{C} 18$ dyes

rescence probes, the optimal dye concentrations were found for the studied cultures. For the probe $\mathrm{C} 2$ it was $1 \mu \mathrm{M}, 10 \mu \mathrm{M}$ - for the C9 and JC-1, $100 \mu \mathrm{M}$ - for the C18 dye. At optimal probe concentrations (and lower) the morphology of human fibroblasts and SPEV cells remained unchanged as compared to these indices for not-labeled cells.

When increasing the concentration of probes in cell suspensions, a reduction of cell viability was found. At lower concentration of the dyes just a slight luminescence of cell organelles was observed.

Fig. 3, A (see inset) shows the HF cells labeled with fluorescent probe $\mathrm{C} 2$. As the figure demonstrates, the

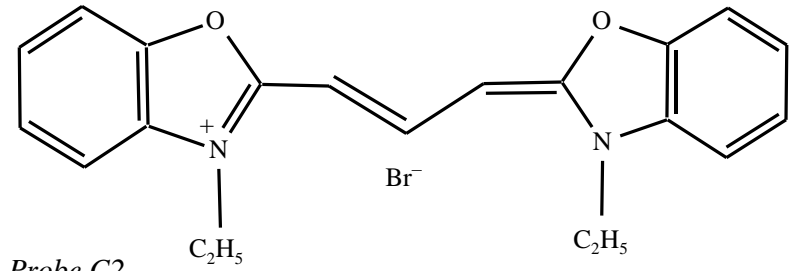

Probe C2

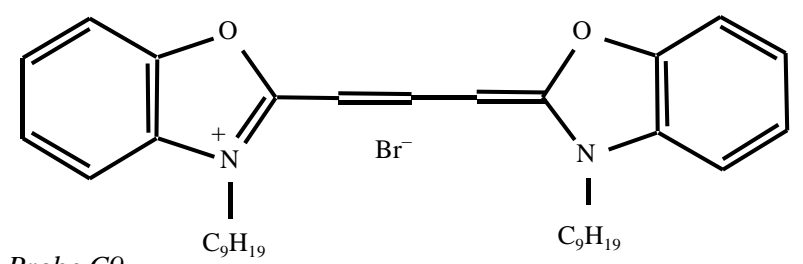

Probe $C 9$

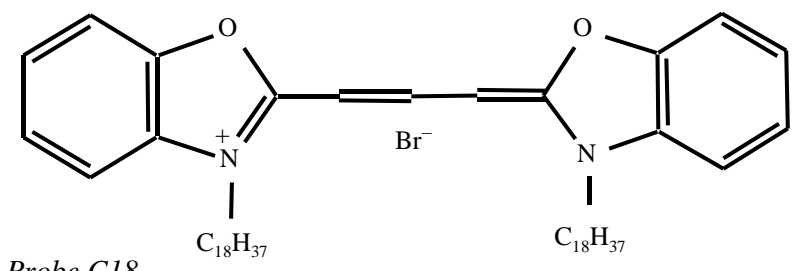

Probe $\mathrm{C} 18$

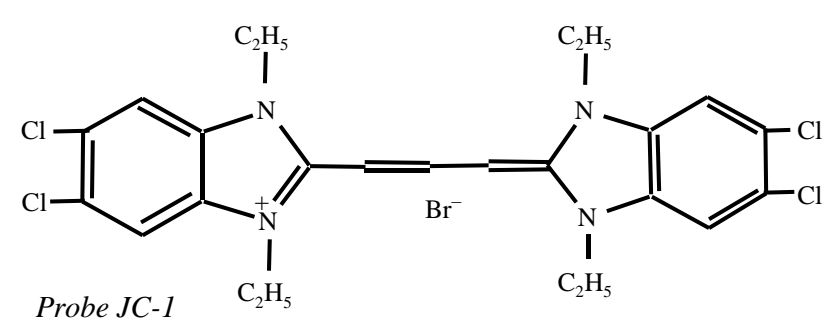

Scheme. Structure of the probes

dye is localized in filamentary structures with the length up to $60 \mathrm{~nm}$, the structures are located in cytoplasm evenly, non-stained nucleus is soundly manifested. There was observed quite evident flash inside the whole cell volume that testifies to the fact of unstable binding of the probe with organelles. During the staining of cell suspension with the probe C9 (Fig. $3, B$, see inset) its distribution in the cell cultures was analogous, however the con- tours of mitochondria were distinct, the baseline light-striking was absent in the visible field.

The cells of HF cultures stained with the C18 dye are presented in Fig. 3, $C$ (see inset). The distribution of this dye in fibroblast cells differs from that for the $\mathrm{C} 2$ and C9 probes. The luminescence was of dotty character, the staining of mitochondria filamentary structures was absent. 

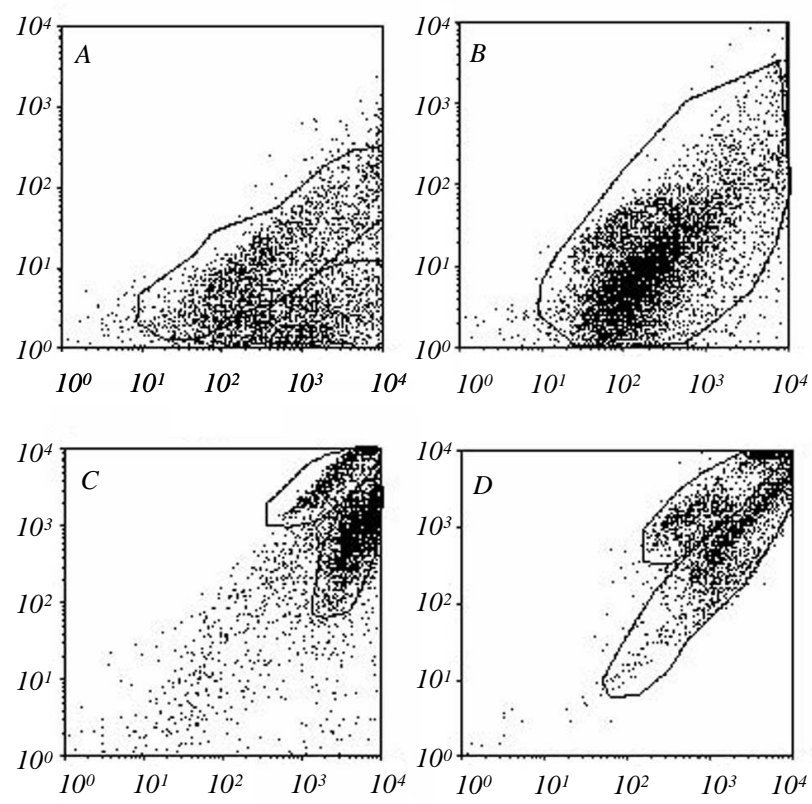

Fig. 6. Cytofluorimetric analysis of cells stained with fluorescent probes: $A-\mathrm{C} 2$ : FL1-H ( $X$-axis) and FL2-H ( $Y$-axis), $\mathrm{R} 1=31.95 \%$, $\mathrm{R} 2=51.89 \% ; B-\mathrm{C} 9:$ FL1-H and FL2-H, R1 $=98.1 \% ; C-\mathrm{C} 18$ : FL1-H and FL2-H, R1 $=52.51 \%, \mathrm{R} 2=28.91 \% ; D-\mathrm{JC}-1: \mathrm{FL} 1-\mathrm{H}$ and FL2-H, R1 $=19.03 \%, \mathrm{R} 2=79.72 \%$

When staining the cells with the probe JC-1, there was revealed a picture morphologically similar to those for the dyes $\mathrm{C} 2$ and $\mathrm{C} 9$, exept for the fact that luminescence of the cell organelles was observed in the orange area (Fig. 4, see inset). There was observed green luminescence, associated with organelles, in cytoplasm. This picture testifies to the presence of the dye in the cells in form of J-aggregates.

The character of distribution of the dyes $\mathrm{C} 2$ and $\mathrm{C} 9$ in the SPEV culture cells differs from that in the HF cells. Separated mitochondria, evenly distributed along the whole SPEV cell, were stained (Fig. 5, A, see inset). Visually the SPEV cell chondriome did not differ significantly from filamentary one of human fibroblasts (Fig. 5, A, B, see inset). As for the probe $\mathrm{C} 18$, its localization in SPEV cells was similar to that in fibroblasts.

Information about the interaction of probes with cells was also obtained by FACS method. The results of flow cytometry of HF culture stained with the carbocyanine probes are shown in Fig. 6. Each graph point corresponds to a cell. The cell coordinates are the intensities of fluorescence at the $520 \pm 15 \mathrm{~nm}(\mathrm{FL} 1-\mathrm{H})$ and $580 \pm 20 \mathrm{~nm}(\mathrm{FL} 2-\mathrm{H})$ fluorescence channels. R1 and
$\mathrm{R} 2$ are cell regions, limited by the parameter of fluorescent intensity at the channels.

Cell fluorescence of HF culture stained with the probe $\mathrm{C} 2$ as well as that of the culture stained with the probe C9 is in a green fluorescence area, region $(\lambda=$ $=530 \mathrm{~nm})($ Fig. 6, $A, B)$.

Fluorescence of the probe $\mathrm{C} 18$ in contrast to the C2 and C9 probes is in the area of red fluorescence $(\lambda=$ $=670 \pm 20 \mathrm{~nm})$ and the cells are distributed into two groups (Fig. 6, C).

Flow cytometry analysis of the HF cell culture stained with the probe JC-1 has shown that the fluorescence in the orange region $(\lambda=585 \pm 20 \mathrm{~nm})$ is inherent for the case under study, moreover the cells are distributed into two groups (Fig. 6, D). In this area Jaggregates, formed on mitochondria with a high transmembrane potential, are luminescent. We induced apoptosis in these cells using etoposide. In this case the shift of fluorescence into green area was observed.

Thus, in fibroblasts the dyes were localized in filamentary structures located along the whole cell, similar to the system of fibroblast mitochondria-chondriome described in the paper [9]. The $\mathrm{JC}-1$ probe is a well-known mitochondrial dye [10]. Its specific binding was proved using FCCP proton translocator. At the potential alteration, orange luminescence changed to green one as a result of the dye transition from polymeric to monomeric form.

When analogous manipulation was performed with the cells of HF cultures, stained with other presumably potential-dependent dyes, their release into the cell cytoplasm and into environment was established in all cases, as well as luminescent quenching as a result of changing a chondriome membrane.

A potential of application of the carbocyanine probes for tracing the fate of some cells during long-term culturing was studied. To investigate a possibility of spontaneous dye transfer from cell to cell in proliferating culture the SPEV and HF cultures were co-cultured. A significant difference in the morphology of fibroblast chondriome and kidney cells allowed us to perform the experiment, which we called «in vitro transplantation».

It has been shown that during co-culturing the C2-stained SPEV and non-stained HF cells, the dye transfer from stained into non-stained cells takes place. 
Fig. 7 (see inset) shows bright luminescence of both SPEV cells and fibroblasts for typical chondriome.

The same situation was observed during staining the HF cells with the probe $\mathrm{C} 2$. The brightly luminescent stained fibroblasts were seen against the background of non-stained SPEV cells. The luminescent pig's kidney cells can be also found around them. When using the probe $\mathrm{C} 9$ at co-culturing stained and non-stained cells the similar results were obtained.

Combined culturing of fibroblast cells labeled with the JC-1 probe with non-stained SPEV cells has demonstrated that there was no transition of the dye from labeled into non-labeled cells, which enables the monitoring of a certain cell line (Fig. 8, $A$, see inset).

We also have found that at the combined culturing of JC-1 labeled SPEV and non-stained fibroblasts no transition of the dye into non-labeled cells was observed (Fig. 8, $B$, see inset).

In addition, the duration of survival of the fluorescent probes in proliferating culture was studied. It has been established that luminescence of probes in cells persisted during the whole period of culture growing till the next re-plating (4-5 days) and longer (1016 days). The luminescence intensity of dyes had a fading character, decreasing along with the cell fission. Carbocyanine probes persisted in fissionable cells throughout 4-8 doublings. In this case localization of the dyes did not change, and luminescence slightly decreased.

Discussion. The studied probes of carbocyanine series were synthesized as analogues of the well-known probes. In the papers $[11,12]$ when investigating an effect of counterion of the cyanine dyes on photophysical properties, the authors observed the quantum yield decrease for iodides, if compared with chlorides or bromides. This is a so-called «heavy atom» effect. Therefore, we synthesized and used mainly bromides.

We studied the properties of probes $\mathrm{C} 2, \mathrm{C} 9, \mathrm{C} 18$, which are the members of alkyl family, differing by the lengths of alkyl chains to reveal the similarity and distinction between the functional characteristics and peculiarities of interaction with the cell cultures. It should be noted that the number of alkyl groups and the level of hydrophobicity affect the character of a dye interactions with intracellular structures [13]. It has been reported [14-16] that, when using carbocyanine probes for labeling cells, localization of probes in cells depends on the applied concentration of dye and the length of alkyl chains.

At low concentrations (below $10 \mu \mathrm{M}$ ) the probe is located on the mitochondria membranes, at high concentrations it reflects the state of endoplasm reticulum. According to the Invitrogen-Molecular Probes' data, the carbocyanine probes with short alkyl chains (C1-C6) at low dye concentration of $0.5 \mu \mathrm{M}$ stain the cell mitochondria, while at concentrations of $5-50 \mu \mathrm{M}$ the staining of the sarcoplasmic reticulum is observed. At the dye concentration used in our experiments the C18 dye seems to stain the lipid sites of endoplasm reticulum whereas the $\mathrm{C} 2$ and $\mathrm{C} 9$ dyes give the information on the state of mitochondria. It has been shown that the probe $\mathrm{C} 18$ is the most lipophilic, has different from the other probes of this type localization in a cell and is characterized by heterogeneous binding character.

One of the dyes frequently used for the assessment of the state of mitochondria in cells is the JC-1 probe, the potential-dependent dye, which specific molecule interaction with mitochondria depends on the transmembrane potential, generated by functioning mitochondria. In the diagnostic set MitoPT (Immunochemistry Technologies, USA) the probe JC-1 serves as a marker of caspase-independent apoptosis due to tracing the changes in functional state of mitochondria in cells. Our studies of the synthesized probe JC- 1 with FACS method also testify to adequacy of this approach. After apoptosis induced by etoposide the shift of cell luminescence from orange towards green area has been demonstrated.

We have found that this probe may be successfully applied for labeling human fibroblasts both at express diagnostics of a cell state and at long-time stay in cells. According to the FACS-analysis data, the fluorescence in orange area is characteristic of the HF cell cultures, stained with the investigated probe JC-1 that corresponds to the luminescence of the mitochondria with high transmembrane potential. We have shown that the probes C2 and C9 stain $100 \%$ of cells in the studied suspension, the stained cell organelles are luminescent in green area. For the cells stained with the probe $\mathrm{C} 18$ the staining of all cells is observed. Their luminescence is recorded in red area. Our results seem be a ground for 
the statement that the application of these probes as potential-dependent ones is restricted.

The authors of [17] have studied the labeling of bone marrow cells with the probe of carbocyanine series CM-DiI (chloromethyl-benzamidodialkylcarbocyanine). CM-DiI is the DiI derivative, hydrophilic properties of which exceed those of DiIC18(3) (1, 1'-dioctadecyl-3,3,3',3'-tetramethylindocarbocyanine perchlorate), that facilitates the preparation of staining solutions for cell suspensions. In the paper [2] the fluorescent lipophilic probe CM-DiI was used for monitoring the bone marrow mesenchymal stromal cells. It has been shown that CM-DiI is not toxic and does not affect the cell proliferation, and the intensity of fluorescence reduces twice after each cell division. This probe provided the tracing of cells minimum for 30 culturing days. The dye PKH-26 (Sigma) (structurally identical to DiIC18(3)), which are also applied for cell labeling in vivo and in vitro, may be preserved in cells for 21 days.

The carbocyanine probes C2, C9, C18 and JC-1, obtained by us, at optimal concentrations are not toxic for the studied cell lines, that is proved by unchanged morphology and proliferative activity of the studied labeled cultures.

The probe, optimal for observation of proliferation cultures, is the probe $\mathrm{C} 9$, which enables the tracing of mitochondria functional state, due to tight binding and providing distinct morphological picture of chondriome.

We have shown that the studied carbocyanine probes are preserved in dividing cells during at least four duplications. It has been found that the carbocyanine probe JC-1 does not transit from cell to cell at combined culturing of labeled and non-labeled cells and can provide the information on a certain cell.

The probes C2, C9, C18 transit from cell to cell. Spontaneous transcellular transition of the studied probes under modeled transplantation in vitro does not allow recommending investigated probes for tracing the fate of transplanted cells in the recipient's organism. At the same time the long-term survival and invariability of the probe properties in cultured cells can be a reason to recommend them for the long-term labeling of biological objects when necessary (e. g. in low tem- perature banks, the coding of cell samples during transportation).

The research was carried out under the STCU grant 4358 support.

Authors thank Dr. Dyubko T. S. for her consulting and fruitful discussion and Timon V. V. for technical assistance.

\section{О. І. Гончарук, I. А. Боровой, О. В. Павлович, Ю. В. Малюкін, В. I. Грищенко}

Новосинтезовані карбоціанінові флуоресцентні зонди, їхня характеристика та поведінка в проліферуючих культурах

Резюме

Мета. Дослідити можливості застосування карбоціанінових флуоресцентних зондів C2, C9, С18 та ЈC-1 для характеристики культур клітин. Методи. Використано морфологічні методи, метод проточної иитофлуориметрії (FACS-аналіз), люмінесцентну мікроскопію. Результати. Показано, що досліджені карбоціанінові зонди зберігаються в клітинах, що діляться, протягом не менш чотирьох подвоєнь. Встановлено, що карбоціаніновий зонд JC-1 не переходить із клітини в клітину при одночасному культивуванні мічених і немічених клітин різних культур. Висновки. Встановлено, що зазначені флуоресцентні зонди можна використовувати при довготривалому культивуванні клітинних ліній. Для спостереження за проліферуючими культурами оптимальним є застосування зондів C9 і JC-1, що дозволяе відслідковувати функціональний стан мітохондрій.

Ключові слова: флуоресценція, зонди, фібробласти людини, культура клітин.

Е. И. Гончарук, И. А. Боровой, Е. В. Павлович, Ю. В. Малюкин, В. И. Грищенко

Новосинтезированные карбоцианиновые флуоресцентные зонды, их характеристика и поведение в пролиферирующих культурах

Резюме

Цель. Исследовать возможности применения карбоцианиновых флуоресцентных зондов C2, C9, C18 и JC-1 для характеристики культур клеток. Методы. Использованы морфологические методы, метод проточной цитофлуориметрии (FACSанализ), люминесиентная микроскопия. Результаты. Показано, что исследуемые карбоцианиновые зонды сохраняются в делящихся клетках в течение не менее четырех удвоений. Установлено, что карбоцианиновый зонд JC-1 не переходит из клетки в клетку при совместном культивировании меченых и немеченых клеток разных культур. Выводы. Определено, что указанные флуоресцентные зонды можно использовать при долговременном культивировании клеточных линий. Для наблюдения за пролиферирующими культурами оптимальным является применение зондов C9 и JC-1, что позволяет отслеживать функциональное состояние митохондрий.

Ключевые слова: флуоресценция, зонды, фибробласты человека, культура клеток. 


\section{REFERENCES}

1. Downing T. W., Garner D. L., Ericsson S. A., Redelman D. Metabolic toxicity of fluorescent stains on thawed cryopreserved bovine sperm cells // J. Histochem. and Cytochem.1991.-39, N 4.-P. 485-489.

2. Ferrari A., Hannouche D., Oudina K., Bourguignon M. In vivo tracking of bone marrow fibroblasts with fluorescent carbocyanine dye // J. Biomed. Mat. Res.-2001.-56, N 3.P. 361-367.

3. Goncharuk E. I., Onischenko E. V., Timon V. V., Petrenko T. F., Borovoy I. A., Maliukin Yu. V., Grishchenko V. I. Application of carbocyanine fluorescent probes for evaluation of the functional state of cell cultures after cryoconservation //Biopolymers and Cell.-2008.-24, N 3.-P. 225-230.

4. Culture of living cells. Methods / Ed. R. Freshney.-M.: Mir, 1989.-333 p.

5. Adams R. L. P. Cell culture for biochemists.-Amsterdam: Elsevier, 1980.-292 p.

6. Smiley S. T., Reers M., Mottola-Hartshorn C., Lin M., Chen A., Smith T. W., Steele G. D., Chen L. B. Intracellular heterogeneity in mitochondrial membrane potentials revealed by a J-aggregate-forming lipophilic cation JC-1 // Proc. Nat. Acad. Sci. USA.- 1991.-88, N 9.-P. 3671-3675.

7. Rossi U. De, Moll J., Spieles M., Bach G., Dahne S., Kriwanek J., Lisk M. Control of the J-aggregation by variation of the N-alkyl-substituents // J. Prakt. Chem.-1995.-337.-P. 203208.

8. Kiprianov A. I., Pilyugin G. P. Synthesis of polymethine dyes // Scientific notes of Kharkiv University.-1937.-10.-P. 91107.

9. Johnson L. V., Walsh M. L., Bockus B. J., Chen L. B. Monitoring of relative mitochondrial membrane potential in living cells by fluorescence microscopy // Annu. Rev. Cell Biol.1988.-4.-P. 155-181.
10. Salvioli S., Ardizzoni A., Franceschi C., Cossarizza A. JC-1, but not DiOC6(3) or rhodamine 123, is a reliable fluorescent probe to assess $\Delta \Psi$ changes in intact cells: implications for studies on mitochondrial functionality during apoptosis // FEBS Lett.-1997.-411.-P. 77-82.

11. Petrov N. Kh., Gulakov M. N., Alfimov M. V., Busse G., Techert $S$. Solvation-shell effect on the cyanine-dye fluorescence in binary liquid mixtures // Z. Physik. Chem.-2007.221. N 4.-P. 537-547.

12. Tatikolov A. S., Shvedova L. A., Derevyanko N. A., Ishchenko A. A., Kuzmin V. A The influence of counterion on photochemistry of cationic indopolycarbocyanine dyes in ions pairs // Chem. Phys. Lett.-1992.-190, N 3-4.-P. 291-297.

13. Malyukin Yu. V., Borovoy I. A., Kavok N. S. Accumulation of oxocarbocyanines with different length of alkyl chains in cells of bone marrow and hepatocytes // Biophyzica.-2007.52, N 4.-P. 667-673.

14. Terasaki M. Fluorescent labeling of endoplasmic reticulum // Meth. Cell Biol.-San Diego: Acad. press, 1989.-Vol. 29.P. 125-135.

15. Terasaki M., Chen L. B., Fujiwara K. Microtubules and the endoplasmic reticulum are highly interdependent structures // J. Cell Biol.-1986.-103.-P. 1557-1568.

16. Terasaki M., Celis J. Labeling of endoplasmic reticulum with DiOC6(3) in cell biology: A laboratory handbook.-Orlando: Acad. press, 1994.-Vol. 2.-P. 381-386.

17. Kruyt M. C., De Bruijn J., Veenhof M., Oner F. C., Van Blitterswijk C. A., Verbout A. J., Dhert W. J. Application and limitations of chloromethyl-benzamidodialkylcarbocyanine for tracing cells used in bone tissue engineering // Tissue Engin.-2003.-9, N 1.-P. 105-115.

УДК 57.085.2:577.336 Надійшла до редакції 15.05.09 